\title{
Erektil Disfonksiyonun Değerlendirilmesinde Hormonal İncelemenin Gerekliliği
}

\author{
Necessity of Endocrine Screening in Men with Erectile Dysfunction
}
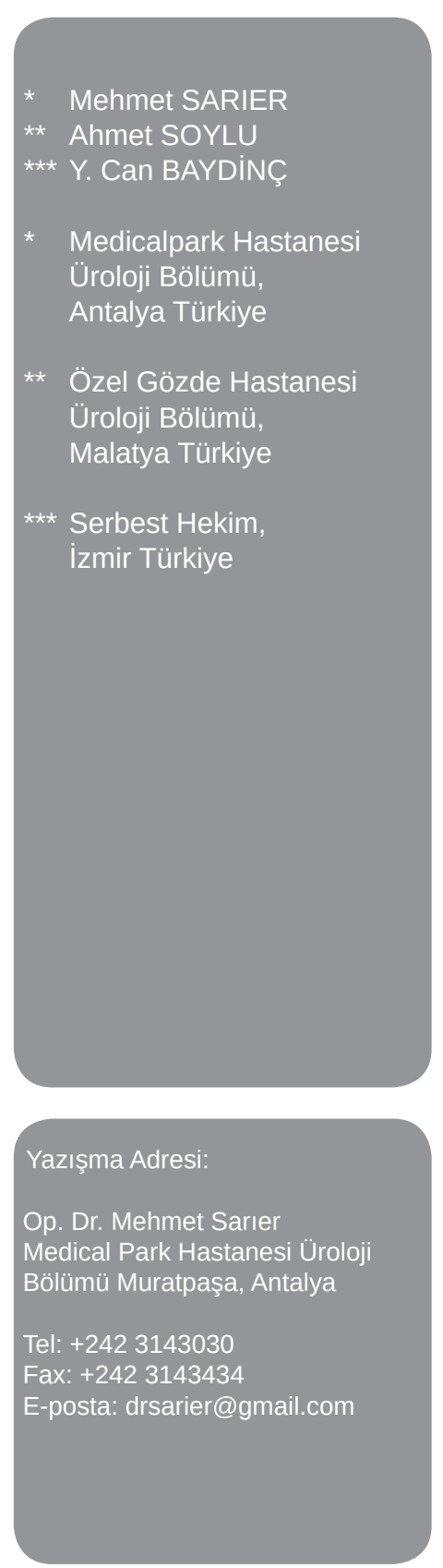

\section{Öz}

Amaç: Erektil Disfonksiyon nedeniyle başvuran hastada yapılacak ilk incelemede rutin hormonal değerlendirmenin yapılıp yapılmaması tartışmalıdır. Bu çalışmada kliniğimize başvuran ve hormonal inceleme yapılan hastalara bu incelemelerin katkısı araştıııldı. Yöntem ve Gereçler: Polikliniğimize erektil disfonksiyon nedeniyle başvuran ve hormonal değerlendirme düşünülen hastalarda FSH, LH, Prolaktin ve Testosteron seviyelerinden en az ikisine bakılarak incelemeler yapıldı. Hormonal bozukluk oranları tespit edilerek bu bozukluların hasta yaşı ile korele olup olmadığına bakıldı. Ayrıca bu değerlendirmeler sonucunda tedavide farklı bir uygulamanın yapılıp yapılmadığı tespit edildi. Bulgular: Ortalama yaşı 46,1 olan 356 hastanın 227'sine (\%63.8) hormonal inceleme yapıldı. FSH yüksekliği \% 9.5 (20/221), LH yüksekliği \%7.1 (16/224), prolaktin yüksekliği \%4.7 (10/211) ve testosteron düşüklüğü \% 3.7 (7/191) hastada tespit edildi. FSH ve LH ile yaş arasında anlamlı pozitif korelasyon, prolaktin ile yaş arasında negatif korelasyon görülürken testesteron ile yaş arasında korelasyon tespit edilmedi. Prolaktin yüksekliği olan 10 hastanın 1 tanesi daha önceden hipofiz adenomu tanısı almış ve tedavi edilmekteydi. Diğer 9 hastada prolaktin değerleri normal sınırın 2 katını geçmediğinden endokrinoloji bilim dalı tarafından ek incelemeye gerek görülmedi. Testosteron düşüklüğü olan 7 hastadan libido azalması olan 2 tanesine testosteron replasmanı yapılırken diğer 5 tanesine gerek görülmedi ve tüm hastalara erektil disfonksiyona yönelik tedaviler uygulandı. Sonuçlar: Bu bulgular erektil disfonksiyon nedeniyle başvuran bir hastada yapılacak ilk incelemede hormonal incelemenin tedaviye ek katkısının çok olmayacağını göstermektedir. Hormonal incelemeler iyi bir anemnez ve fizik muayeneyi takiben sadece gerekli olgularda istenmelidir.

Anahtar Kelimeler: Erektil Disfonksiyon, Hormon, Testosteron

\begin{abstract}
Objectives: It is an issue of debate whether or not to perform hormonal testing as a first-line investigation in patients with erectile dysfunction. This study aimed to assess the contribution of hormonal testing to the diagnostic investigations of patients who present with erectile dysfunction. Methods: Investigations were performed in patients who applied to our andrology clinic due to erectile dysfunction and in whom hormonal causes were suspected,
\end{abstract}


by looking at least two of the $\mathrm{FSH}, \mathrm{LH}$, prolactin and testosterone levels. The rates of hormonal disturbances and their correlation with age were determined. Additionally, whether any modification was performed or not according to the results of these tests was noted. Results: Hormonal investigation was performed in $227(63.8 \%)$ of 356 patients. The increased levels of $\mathrm{FSH}, \mathrm{LH}$,prolactin and decreased level of testosterone were seen in 9.5\% (20/221), 7.1\% (16/224), $4.7 \%(10 / 211)$ and $3.7 \%(7 / 191)$ of the patients. There was a positive correlation between FSH and $\mathrm{LH}$ and age, a negative correlation between prolactin and age,and no correlation between testosterone and age. One of the 10 patients with prolactin increase had been diagnosed and been receiving treatment for hypophysis adenoma. Since the level of prolactin was not twice the normal level no further examination was requested in the remaining 9 patients by the endocrinologists. Testosterone replacement was given in two of 7 patients with decreased libido. In the remaining 5 patients no replacement was needed. Conclusions: Our findings indicate that performing the hormonal investigation as a first line investigation in an erectile dysfunction patient does not contribute to the treatment additionally. Hormonal investigations should be performed after detailed history and physical examination and only in necessary cases.

Keywords: Erectile Dysfunction, Hormone, Testosterone

\section{Giriş}

Erektil disfonksiyon (ED) tatmin edici seksüel performansa izin veren yeterli ereksiyonu elde etmede ve sürdürmedeki yetersizlik olarak tanımlanmaktadır(1). Cinsel yaşam açısından eşlerin her ikisinin de ortak tatmini başarmada yetersizliğe neden olan ED, eşlerin mutluluğunu, erkeğin kendine saygısını, toplumsal ilişkilerini zedeleyen ve ciddi psikolojik sorunlar oluşturabilen bir patolojidir (2). ED etyolojisi temel olarak organik, psikojenik ve karma olarak sınıflandırılmıştır (3). Erektil disfonksiyon etyolojisinde \%80 nin üzerinde organik faktörler rol oynamaktadır(4). Organik kökenli ED; nörojenik, hormonal, vasküler, anatomik, travma ve ilaca bağlı olmak üzere altı alt gruba ayrılmıştır(5). ED'nun organik sebeplerinden biride hormonal bozukluklardır. ED'un hormonal etyolojisinin araştırılması sırasında, Testesteron, Luteinizan Hormon (LH), Folikül Uyarıcı Hormon (FSH), Prolaktin ve Tiroid hormonlarına bakılmaktadır (6-8). ED etyoloji- sinin araştırılmasında hormonal tetkiklerin rutin olarak bakılması bugün için tartışma konularından biridir. Bu çalışmada ED şikayetleri ile polikliniğimize başvuran hastalarda rutin olarak yapılan hormonal incelemelerin katkısını değerlendirmeyi amaçladık.

\section{Gereç ve Yöntem}

Hastanemiz Üroloji polikliniğine son 5 yıllık dönem içinde doğrudan ED yakınması ile başvuran veya başka bir ürolojik yakınmayla başvurup erektil fonksiyon sorgulaması sırasında ED tespit edilen 356 hastanın sonuçları retrospektif olarak değerlendirildi.

Erektil disfonksiyon cinsel ilişki için gerekli olan, penisin vaginaya girişini sağlayacak derecede ereksiyonun başlatılmasında, sağlanmasında ve sürdürülmesinde yetersizlik olarak tanımlandı ve bu şekilde yakınması olan hastalar ED hastası olarak kabul edildiler. Bütün hastaların ayrıntılı sorgulamayla, anamnezleri alındı. Erektil disfonksiyonun derecesi; hastanın cinsel fonksiyonları için yeterli bir ereksiyona erişme ve sürdürme yeteneğini, tatmin derecesini ve belirli bir tedavinin güvenirliliğini yeterli bir şekilde yansıtan Ereksiyon İşlevi Uluslararsı Değerlendirme Formuna (IIEF-5) göre değerlendirildi. Hastalara detaylı anamnez, sistemik, nörolojik ve ürogenital muayene, biyokimyasal ve hormonal değerlendirme, penil renkli doppler ultrasonografi, kavernözografi ve nörofizyolojik testlerden oluşan ayrıntılı değerlendirmeleri yapıldı.

Bu hastaların 227'sinde (\%63.8) anamnez ve fizik muayeneyi takiben hormonal değerlendirme amacıyla, testosteron, prolaktin, LH ve FSH hormonlarından en az iki tanesine bakıldı. Kan örnekleri sabah 8:0010:00 saatleri arasınnda alındı. Radioimmunoassay yöntemi ile serum hormon düzeyleri ölçüldü. Hormonal bozukluğun tespiti için normal değerler total testesteronda; (212 - $1511 \mathrm{ng} / \mathrm{dl})$, prolaktinde; (2,5 - 17 ng/ml), LH'da; (1,4 - 7,7 mlU/ml), FSH'da ise; (1,5 - 14 $\mathrm{ng} / \mathrm{dl})$ olarak kabul edildi. Bu şekilde hormonal problemi olan hastalar tespit edildi ve serum hormon düzeyleri ile hasta yaşı arasındaki ilişki istatistiksel olarak değerlendirildi.

İstatistiksel değerlendirme: İstatistiksel analiz için Statistical Package for the Social Sciences (SPSS) 22 for Windows programı kullanıldı. Yaş ile hormon düzeyleri arasındaki ilişki Pearson korelasyon katsayısı ile değerlendirildi. $p<0,05$ istatistiksel olarak anlamlı kabul edildi. 


\section{Bulgular}

ED tanısı konan 356 hastadan hormon değerlerine bakılan 227 hastanın ortalama yaşı 46,1 (23 - 71) idi. FSH yüksekliği \%9.5 (20/221), LH yüksekliği \%7.1 (16 / 224), prolaktin yüksekliği \%4.7 (10 / 211) ve testosteron düşüklüğü \%3.7 (7 / 191) hastada tespit edildi.(Tablo 1).

FSH ve LH ile yaş arasında anlamlı pozitif ilişki mevcut iken $(p<0.05)$, Prolaktin ile yaş arasında ise negatif ilişki görüldü $(p<0.05)$. Testosteron ile yaş arasında ise ilişki tespit edilmedi ( $p>0.05)$.

Prolaktin yüksekliği olan 10 hastanın bir tanesi (\%0.47) normal üst sınır değerinin 2 katından daha yüksek prolaktin değerine sahipti. Bu hasta daha önceden hipofiz adenomu tanısı almış ve hiperprolaktinemi nedeniyle medikal tedavi almaktaydı. Diğer 9 hastada (\%4.2) prolaktin değerleri normal üst sınırın 2 katının altında idi. Endokrinoloji Bölümü tarafından konsülte edilen bu 9 hastada ek inceleme ve tedaviye gerek görülmedi. Testosteron düşüklüğü olan 7 hastadan anamnezde libido azalması olan 2 tanesine (\%1.1) testosteron replasmanı yapılırken, anamnezinde libido kaybı tarif etmeyen diğer 5 hastaya (\%2.6) replasmana gerek görülmedi ve tüm hastalara erektil disfonksiyona yönelik gerekli tedaviler uygulandı.

\section{Tartışma}

Erektil disfonksiyon etiyolojisinde hormonal patolojilerin görülme sıklığı \%2-33 arasında değişmektedir(9). Kendi içinde de testosteron düşüklüğü \%4.3-19.3, hiperprolaktinemi \%1-5 ve tiroid hastalığı \%1'den az$\operatorname{dir}(10)$.

Endokrinolojik değerlendirmede en başta LH, testosteron, FSH, ve prolaktin hormonlarına bakılmaktadır(11). Bu hormonlar içerisinde en önemli yeri testosteron hormonu oluşturmaktadır. Erkek cinsel fonksiyonları için önemli yeri olan bu hormonun gerek ereksiyon gerekse de libido üzerine direk etkili olduğu bulunmuştur(12).

Erektil disfonksiyonu olan hastalarda rutin endokrinolojik değerlendirmenin gerekliliği tartışmalı bir konudur. Bununla birlikte, hipogonadizm ve hiperprolaktinemi seyrek görülen cinsel fonksiyon bozuklukları nedenleri olmalarına karşın, uygun tedavi ile en iyi sonuç alınan grubu oluşturmaktadır. Johnson ve ark. 330 ED hastasının sadece 7'sinde (\%2.1) endokrinopati tespit etmişlerdir(13). Bu 7 hastanın 5'inde testiküler atrofi, 6'sında ise azalmış libido bulunmuştur. Endokrinopatili bütün hastalarda ya azalmış libido yada testiküler atrofi gözlemlenmiştir. Buna dayanarak araştırmacılar sadece hipogonadizmin klinik bulgularının (azalmış libido ve/veya testiküler atrofi) olduğu ED'li hastalarda hormonal incelemenin yapılması gerektiğini belirtmişlerdir.

Buvat ve ark. ise toplam 1022 ED'li hastada yapmış oldukları çalışmada \%6,6 sında düşük serum testosteron düzeyi tespit edilmiştir(14). Bu çalışmada düşük testosteron düzeyinin prevelansının yaş ile arttığı bulunmuştur. Bunlara dayanarak serum testosteron ölçümünün 50 yaşın altındaki hastalar için düşük libido ve/veya anormal fizik muayene bulgusu mevcudiyetinde yapılması gerektiğini, ancak 50 yaşın üstündeki her hastada yapılması gerektiğini belirtmişlerdir.

Türkiye'de yapılan bir çalışmada erektil disfonksiyonlu 262 hasta ile 53 sağlıklı erkeğin serum testosteron ve prolaktin düzeyleri karşılaştırılmıştır(7). Hasta grubunda saptanan hipotestosteronizm ve hiperprolaktinemi oranları sırasıyla \%11 ve \%9.5 olarak saptanmıştır. Kontrol grubunda ise bu oranlar her iki parametre için \%3.7 olarak belirlenmiştir. İki grup arasında düşük testosteron ve yüksek prolaktin oranları açısından istatistiksel bir fark tespit edilememiştir. (hi-

\begin{tabular}{|c|c|c|}
\hline Hormonal bozukluğun tipi & Hasta sayısı & Yüzdesi \\
\hline FSH yüksekliği & 20 & 9.5 \\
\hline LH yüksekliği & 16 & 7.1 \\
\hline Prolaktin yüksekliği & 10 & 4.7 \\
\hline Testesteron düşüklüğü & 7 & 3.7 \\
\hline
\end{tabular}


potestosteronizm için $p=0,104$, hiperprolaktinemi için $p=0,171)$. Hasta ve kontrol grubunun tüm hastalarının ortalama serum FSH, LH, prolaktin ve testosteron düzeyleri arasında istatistiksel bir fark bulunamamıştır. Hormonal bozukluğu düşünüdürecek risk faktörleri değerlendirildiğinde 2 grup arasında hasta yaşı, ED süresi, sigara içme öyküsü ve süresi, kronik hastalık mevcudiyeti ve ED tipi açısından anlamlı farklılıklar bulunamamıştır. Bütün bunlara dayanılarak araştırmacılar yukarıda sununlan 2 çalışmaya benzer biçimde erektil disfonksiyonlu hastaların ilk değerlendirilmesinde hormonal incelemenin gerekli olmadığını, ancak dikkatli bir anamnez ve fizik muayene bulgularına dayanarak yapılması gerektiğini belirtmişlerdir. Testosteron düşüklüğü hipergonodotropik, hipogonodatropik veya ögonodatropik olarak görülebilir. Testosteron düşüklüğünde hormonal tedavinin başlanması da tartışmalı konulardan birisidir. Buvat ve ark. 1022 hastadan oluşan ED çalışmasında testosteron düşüklüğünü \%6.6 olarak buldukları halde androjen replasmanı yapılması gereken hasta oranını sadece \%2.6 olarak bulmuşlardır(14). Benzer bir değer bizim çalışmamızda da ortaya çıkmıştır. Testosteron düşüklüğü oranı \%3.7 iken, ED ve libido azalması tarif eden grup sadece \%1.1 idi. Yaş ile ilişkisi dikkate alınmadan incelendiğinde androjen replasmanının ancak anlamlı anamnez ve pozitif fizik muayene bulguları durumunda uygun olacaği ortaya çıkmaktadır. Nitekim erektil disfonksiyonlu bazı erkeklerde düşük testosteron düzeyi erektil disfonksiyonun nedeni olmaktan ziyade sonucu da olabilir. Düşük testosteron seksüel aktivitenin azalmasından, stres veya depresyondan da kaynaklanabilir. Çünkü bu etkiler testosteron sekresyonunu inhibe edebilirler(15).

Testosteronun yaşla ilişkisi uzun zamandır bilinmektedir. Serbest testosteron veya seks hormonu bağlayan globulin (SHBG) ile bağlı olmayan testosteron (serbest testosteron) hedef hücrelerde aktif olan testosterondur. Serum serbest testosteron düzeyi maksimum seviyesine 20-30 yaşlarında ulaşırken, 35 yaşlarında düşüş göstererek 75 yaşında \%50 oranında azalır(16). Yaşlanma ile gözlenen hipogonadizm prevelansı konusunda belirgin bir görüş yoktur. Erektil disfonksiyonu bulunan hastalarda 50 yaş üzerinde serbest testosteron oranının anlamlı şekilde azaldığı görülmektedir (17). Testosteron seviyesindeki azalmaya çeşitli risk faktörleri de eşlik eder. Bu risk faktörleri arasında genetik yapı, sosyoekonomik durum, obezite, sigara, kalp hastalığı, diabet, renal, hepatik ve pulmoner yetmezlik sayılabilir. Yaşlılıkta androjen- lere karşı doku duyarlılığı da farklıdır. Korpus kavernozum bölgesindeki androjen reseptör konsantrasyonu da daha az bulunmuştur(18). Bütün bunlar nedeniyle yaşılıardaki testosteron ihtiyacı halen tartışmalıdır.

Hiperprolaktinemi, ED, galaktore, jinekomasti ve infertilite ye yol açabilir. Hiperprolaktinemi tüm ED içinde \%1-5 arasında görülmektedir $(13,19)$. Tüm bu seriler ile karşılaştırıldığında bizim çalışmamızda da hiperprolaktinemi oranı Tüm ED hasta grubu içinde \%4.7 olarak bulunmuştur. Bodie ve ark. 2306 ED'li hasta üzerinde yaptıkları çalışmada prolaktin yüksekliğini \%4.6 oranında tespit etmiş, prolaktin düzeyi 50 $\mathrm{ng} / \mathrm{dl}$ üzerinde olan hasta oranını ise $\% 0.43$ olarak bulmuşlardır, bunun sonucunda Prolaktin anormalliğinin düşük prevelansı nedeniyle rutin inceleme önermemişlerdir(20). Benzer bir şekilde bizim çalışmamızda ise bu oran \%0.47'dır.

Hiperprolaktinemi nedeni idiyopatik veya hipofiz adenomuna bağlı olabilir. Netto ve ark. 600 randomize hastanın katıldığı bir çalışmada ılımlı prolaktin yüksekliğini (17-35 ng/ml ) \% 3.8 olarak bulmuşlardır(21). Bu oran bizim çalışmamızda ise \%4,7'dir. Yine aynı çalışmada araştırmacılar serum prolaktin düzeyi 35 ng/dl nin altında olan hastalarda bromokriptin tedavisi ile serum prolaktin düzeylerinde azalma izlemiş; fakat, sadece bir hastada tam ereksiyon elde etmişlerdir. Serum prolaktin düzeyi $40 \mathrm{ng} / \mathrm{ml}$ nin üzerinde olan 11 hastanın ise 9'unda tedavi sonrası normal prolaktin seviyelerine ulaşılmış ve tam ereksiyon \%77.7 oranında gerçekleşmiştir. Bu bulgular, prolaktini hafif derecede yüksek olan hastalarda erektil disfonksiyonun altında psikojenik veya başka bir organik sebebin yatabileceğini düşündürmektedir.

LH düzeylerinin artması ED riskini artırmaktadır. Yalnız LH artması ile ED prevelansı arasında lineer bir eğilim yoktur(22). Aynı şekilde LH düzeyleri yaşla birlikte artış göstermekte olup özellikle 70'li yaşlardan sonra belirgin olarak artmaktadır(23). Bizim çalışmamızda da LH yüksekliği literaturle benzer olarak yaşla birlikte pozitif korelasyon göstermiştir.

\section{Sonuç}

Erektil disfonksiyon etyolojisinde rutin olarak olarak hormonal incelemelerin yapılması halen tartışma konusu olmaya devam etmektedir ve standardizasyon sağlanamamıştır. ED'da Hormonal değerlendirme ancak libido kaybı ve anormal fizik muayene bulguları varlığında hesaba katılmalıdır. Testosteron dü- 
şüklüğü saptanan hastalarda androjen replasmanı başka bir patoloji rastlanmadığı taktirde ancak libido kaybı mevcudiyetinde düşünülmelidir. Ilımlı prolaktin yüksekliğinin varlığında direkt hiperprolaktinemi tedavisine başlanmamalı, ED'ye yol açabilecek başka organik sebepler aranmalıdır. Hormonal değerlendirmelerin gerekliliği ile ilgili daha geniş serileri içine alan prospektif kontrollü çalışmaların yapılmasına ihtiyaç vardır.

\section{Kaynaklar}

1. Celik O, Ipekci T, Akarken I, Ekin G, Koksal T. To evaluate the etiology of erectile dysfunction: What should we know currently? Arch Ital di Urol Androl organo Uff [di] Soc Ital di Ecogr Urol e Nefrol. 2014;86(3):197-201.

2. Ghanem HM, Salonia A, Martin-Morales A. SOP: Physical Examination and Laboratory Testing for Men with Erectile Dysfunction. J Sex Med. 2013;10(1):108110.

3. Tang Z, Li D, Zhang X, et al. Comparison of the simplified International Index of Erectile Function (IIEF-5) in patients of erectile dysfunction with different pathophysiologies. BMC Urol. 2014;14:52.

4. Yafi FA, Jenkins L, Albersen M, et al. Erectile dysfunction. Nat Rev Dis Prim. 2016;2:16003.

5. Hatzimouratidis K, Amar E, Eardley I, et al. Guidelines on Male Sexual Dysfunction: Erectile Dysfunction and Premature Ejaculation. Eur Urol. 2010;57(5):804814.

6. Maseroli E, Corona G, Rastrelli G, et al. Prevalence of Endocrine and Metabolic Disorders in Subjects with Erectile Dysfunction: A Comparative Study. J Sex Med. 2015;12(4):956- 965.

7. Acar D, Çayan S, Bozlu M, Akbay E. IS routine hormonal measurement necessary in initial evaluation of men with erectile dysfunctıon? Arch Androl. 2004;50(4):247-253.

8. Bhasin S, Enzlin P, Coviello A, Basson R. Sexual dysfunction in men and women with endocrine disorders. Lancet. 2007;369(9561):597-611.

9. Papagiannopoulos D, Khare N, Nehra A. Evaluation of young men with organic erectile dysfunction. Asian J Androl. 2015;17(1):11-16.

10.Petak SM, Nankin HR, Spark RF, Swerdloff RS, Rodriguez-Rigau LJ, American Association of Clinical Endocrinologists. American Association of Clinical Endocrinologists Medical Guidelines for clinical practice for the evaluation and treatment of hypogonadism in adult male patients--2002 update. Endocr Pract.
8(6):440-456.

11. Kupelian V, Shabsigh R, Travison TG, Page ST, Araujo AB, McKinlay JB. Is There a Relationship Between Sex Hormones and Erectile Dysfunction? Results From the Massachusetts Male Aging Study. J Urol. 2006;176(6):2584-2588.

12. Rajfer J. Relationship between testosterone and

erectile dysfunction. Rev Urol. 2000;2(2):122-128. 13. Johnson AR, Jarow JP. Is routine endocrine testing of impotent men necessary? J Urol. 1992;147(6):15423-4.

14. Buvat J, Lemaire A. Endocrine screening in 1,022 men with erectile dysfunction: clinical significance and cost-effective strategy. J Urol. 1997;158(5):17641767.

15.Buvat J. [Hormones and male sexual behavior: physiological and physiopathological data]. Contracept Fertil Sex. 1996;24(10):767-778.

16.Vermeulen A, Kaufman JM, Giagulli VA. Influence of some biological indexes on sex hormone-binding globulin and androgen levels in aging or obese males. J Clin Endocrinol Metab. 1996;81(5):1821-1826.

17. Yavuz BB, Ozkayar N, Halil M, et al. Free testosterone levels and implications on clinical outcomes in elderly men. Aging Clin Exp Res. 2008;20(3):201206.

18.Gonzalez-Cadavid NF, Swerdloff RS, Lemmi CAE, Rajfer J. Expression of the Androgen Receptor Gene in Rat Penile Tissue and Cells during Sexual Maturation*. Endocrinology. 1991;129(3):1671-1678.

19.Akpunonu BE, Mutgi AB, Federman DJ, York J, Woldenberg LS. Routine prolactin measurement is not necessary in the initial evaluation of male impotence. J Gen Intern Med. 1994;9(6):336-338.

20.Bodie J, Lewis J, Schow D, Monga M. Laboratory Evaluations of Erectile Dysfunction: An Evidence Based Approach. J Urol. 2003;169 (6):2262-2264.

21. Netto Júnior NR, Claro $\mathrm{J}$ de $A$. The importance of hyperprolactinemia in impotence. Rev Paul Med. 1993;111(6):454-455.

22. Çalışkan S, Koca O, Öztürk M, Akyüz M, Karaman i. Hormonal evaluation in erectile dysfunction Erektil disfonksiyonda hormonal değerlendirme. Turkish J Urol. 2012;38(1).

23. Margolese HC. The Male Menopause and Mood: Testosterone Decline and Depression in the Aging Male-Is There a Link? J Geriatr Psychiatry Neurol. 2000;13(2):93-101 